\title{
Comparative evaluation of total RNA extraction methods in Theobroma cacao using shoot apical meristems
}

\author{
D.V. Silva', S.M.J. Branco', I.S.A. Holanda², S. Royaert ${ }^{3}$, J.C. Motamayor ${ }^{4}$, \\ J.P. Marelli ${ }^{4}$ and R.X. Corrêa ${ }^{5}$ \\ ${ }^{1}$ Programa de Pós-Graduação em Genética e Biologia Molecular, \\ Universidade Estadual de Santa Cruz, Ilhéus, BA, Brasil \\ 2Departamento de Ciências Vegetais, Universidade Federal Rural do Semi-Árido, \\ Mossoró, RN, Brasil \\ ${ }^{3}$ Mars Center for Cocoa Science, Barro Preto, BA, Brasil \\ ${ }^{4}$ MARS Inc. c/o USDA-ARS, Subtropical Horticulture Research Station, Miami, FL, \\ USA \\ ${ }^{5}$ Departamento de Ciências Biológicas, Universidade Estadual de Santa Cruz, \\ Ilhéus, BA, Brasil \\ Corresponding author: R.X. Corrêa \\ E-mail: ronanxc@uesc.br \\ Genet. Mol. Res. 15 (1): gmr.15017364 \\ Received August 5, 2015 \\ Accepted October 20, 2015 \\ Published March 4, 2016 \\ DOI http://dx.doi.org/10.4238/gmr.15017364
}

\begin{abstract}
Theobroma cacao is a species of great economic importance with its beans used for chocolate production. The tree has been a target of various molecular studies. It contains many polyphenols, which complicate the extraction of nucleic acids with the extraction protocols requiring a large amount of plant material. These issues, therefore, necessitate the optimization of the protocols. The aim of the present study was to evaluate different methods for extraction of total RNA from shoot apical meristems of $T$. cacao 'CCN 51' and to assess the influence of storage conditions for the meristems on the extraction. The study also aimed to identify the most efficient protocol for RNA extraction using a small amount of plant
\end{abstract}


material. Four different protocols were evaluated for RNA extraction using one shoot apical meristem per sample. Among these protocols, one that was more efficient was then tested to extract RNA using four different numbers of shoot apical meristems, subjected to three different storage conditions. The best protocol was tested for cDNA amplification using reverse transcription-polymerase chain reaction; the cDNA quality was determined to be satisfactory for molecular analyses. The study revealed that with the best RNA extraction protocol, one shoot apical meristem was sufficient for extraction of high-quality total RNA. The results obtained might enable advances in genetic analyses and molecular studies using reduced amount of plant material.

Key words: Nucleic acid; cDNA; RT-qPCR; Endogenous gene actin; Plant RNA; Transcriptomics

\section{INTRODUCTION}

RNA extraction has always been a challenge in the progress of molecular research. Several studies require RNA samples of high quality and quantity for analyses. RNA extraction in some plants is difficult due to the presence of proteins, polysaccharides, and polyphenolic compounds. The presence of proteins causes errors, for example, incorrect quantification of sample concentration; the polysaccharides contaminate the RNA because they have similar physical and chemical characteristics and precipitate with the nucleic acid; the polyphenols oxidize and bind to nucleic acids (Mattheus et al., 2003; Sharma et al., 2003). In this context, it is necessary to adapt the existing protocols or to develop new protocols (Chang et al., 1993; Mitra and Kootstra, 1993; Salzman et al., 1999; Zeng and Yang, 2002; Gesteira et al., 2003; Gasic et al., 2004) for extraction of the desired quality and quantity of RNA.

Several RNA extraction protocols are based on the elimination of proteins, polyphenols, and polysaccharides (Hu et al., 2002; Vasanthaiah et al., 2008; Rai et al., 2010; Ghawana et al., 2011; Rubio-Pina and Zapata-Perez, 2011; Dash, 2013). The type of reagents and homogenization procedures used in the extraction process modifies the RNA extraction efficiency (Portillo et al., 2006). The extraction protocols generally utilize reagents such as acidic guanidinium thiocynate, cetyltrimethylammonium bromide (CTAB), sodium dodecyl sulfate (SDS), phenol, chloroform, lithium chloride, sodium acetate, among other reagents, in order to obtain pure RNA samples free from proteins, polysaccharides, and polyphenolic compounds (Gesteira et al., 2003; Verica et al., 2004).

Several protocols have been developed to efficiently extract RNA. Various companies now offer kits to optimize the extraction procedures; such kits reduce the time of extraction but are often costly. However, generally, a single kit or a protocol does not always results in satisfactory quality and quantity of RNA, extracted from all types of plant tissues, requiring tissue-specific modifications (Yu et al., 2012).

Many extraction protocols require a significant amount of plant material; however, depending on the conditions encountered in the field, plant material available for collection could be limiting. Therefore, studies that seek to optimize the extraction conditions using reduced amount of plant material are extremely important for the advancement of molecular analyses (Moser et al., 2004; Portillo et al., 2006; Christou et al., 2014).

In the present study, we evaluated four different methods for extracting total RNA from 
shoot apical meristems of Theobroma cacao (cacao), a species with high levels of proteins, polyphenols, and polysaccharides. This tree is of great economic importance because of the production of cocoa liquor, cocoa butter and pulp, and derivatives as ice cream, jellies, cosmetics and chocolate, and it is a target of several genetic studies (Araújo et al., 2009; Silva et al., 2011, 2014). We also used three storage conditions and four different numbers of shoot apical meristems for identifying the most efficient protocol.

\section{MATERIAL AND METHODS}

\section{Plant material}

The shoot apical meristems used in this study were collected from approximately 6-yearold cacao "Colección Castro Naranjal" (CCN) 51 trees growing at the Mars Center for Cocoa Science, Barro Preto, Bahia, Brazil (1442'45.021171'"S and 39²2'13.008369'W). Healthy and active meristems, about $6 \mathrm{~mm}$ in size, were selected for use in the experiments (Figure 1).

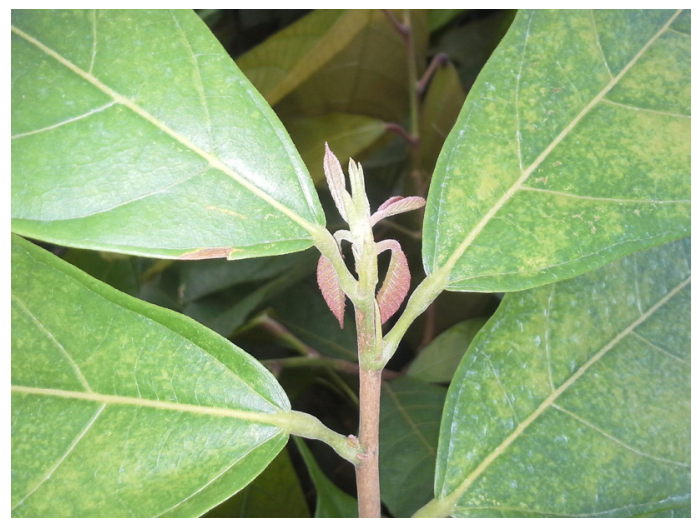

Figure 1. Active and healthy shoot apical meristem of Theobroma cacao.

\section{RNA extraction}

Four different protocols for RNA extraction from the shoot apical meristems were tested: Protocol 01 (Verica et al., 2004); Protocol 02 (Gesteira et al., 2003); ZR Plant RNA mini PrepZymo kit (\#R2024, Zymo Research, Irvine, CA, USA); and RNAqueous Total RNA Isolation kit (\#AM1912, Life Technologies, Carlsbad, CA, USA). For each protocol, one shoot apical meristem was used. It was macerated using a mortar and pestle in liquid nitrogen; the macerate was transferred to 2-mL plastic tubes and processed as per the protocols or the recommendations of the manufacturers of the kits used.

The influence of the number of apical meristems used (one, three, five, or ten) and their storage conditions (lyophilized, stored in freezer at $-80^{\circ} \mathrm{C}$, and fresh apical meristems) on the performance of the most efficient protocol was also tested by assessment of RNA concentrations obtained from the extracted samples. The extracted total RNA samples were purified with RNeasy Mini Kit (\#74106, Qiagen, Valencia, CA, USA), treated with RQ1 RNase-Free DNase (\#M6101, Promega, Madison, WI, USA), quantified with a spectrophotometer GeneQuant ${ }^{\mathrm{TM}}$ pro RNA/DNA Calculator (Amersham Biosciences, England, UK), and stored in a freezer at $-80^{\circ} \mathrm{C}$. 


\section{Statistical analysis}

All tests were performed on five biological replicates. BioEstat 5.3 (Ayres, 2011) was used for determining the average RNA extracted with each protocol, analysis of variance $(P<0.01$ by ANOVA), and for performing the Tukey test $(P<0.05)$.

\section{cDNA synthesis}

The extracted RNA was used for cDNA synthesis. cDNA was synthesized with SuperScript $^{\circledR}$ VILO ${ }^{\mathrm{TM}}$ cDNA Synthesis Kit (Invitrogen, Carlsbad, CA, USA) and stored in a freezer at $-20^{\circ} \mathrm{C}$. A $20-\mu \mathrm{L}$ reaction mixture consisted of the following reagents: $4 \mu \mathrm{L} 5 \mathrm{X}$ Vilo Reaction Mix, $2 \mu \mathrm{L}$ 10X SuperScript Enzyme Mix, $4 \mu \mathrm{L}$ total RNA, and $10 \mu \mathrm{L}$ nuclease-free water. The reactions were incubated in a C1000 Thermal Cycler (Bio-Rad, Hercules, CA, USA) at $25^{\circ} \mathrm{C}$ for $10 \mathrm{~min}, 42^{\circ} \mathrm{C}$ for $120 \mathrm{~min}$, and $85^{\circ} \mathrm{C}$ for $5 \mathrm{~min}$. The synthesized cDNA was quantified using the spectrophotometer, GeneQuant ${ }^{\mathrm{TM}}$ pro RNA/DNA Calculator and stored in a freezer at $-20^{\circ} \mathrm{C}$.

\section{Relative standard curve}

The cDNA was diluted in a 1:2 proportion with nuclease-free water, amplified on an Applied Biosystems ${ }^{\circledR} 7500$ Real-Time PCR system (Applied Biosystems, Foster City, CA, USA) and quantified using the Relative Standard Curve method. The endogenous control gene, actin (Table 1), specific for T. cacao, was used to ensure the suitability of the samples for molecular analyses.

Table 1. Primers used for amplification of the endogenous actin gene (Pinheiro et al., 2011), showing the amplification efficiency, and $\mathrm{R}^{2}$ obtained from RT-qPCR.

\begin{tabular}{|c|c|c|c|c|}
\hline Endogenous gene & Sequence & Fragment size (bp) & Efficiency & $\mathrm{R}^{2}$ \\
\hline Actin & 5'-TCСTCTTCCAGCCATCTCTC-3' (F) & 171 & 1.91 & 0.99 \\
\hline & 5'-TCTCCTTGCTCATTCGGTCT-3' (R) & & & \\
\hline
\end{tabular}

$\mathrm{R}^{2}$ is the correlation coefficient.

Sybr Green Master Mix (Applied Biosystems) was used for quantification. The concentration of different reagents in each $25 \mu \mathrm{L}$ reaction was: 2X SYBR Green Master Mix, $0.05 \mathrm{mM}$ primers (forward and reverse), and one of the five different cDNA concentrations (400, 200, 100,50 , and $25 \mathrm{ng} / \mu \mathrm{L}$ ). All the samples, including the negative control (contained nucleasefree water in place of cDNA), were analyzed in triplicate. The amplification conditions were as follows: $50^{\circ} \mathrm{C}$ for $2 \mathrm{~min}, 95^{\circ} \mathrm{C}$ for $10 \mathrm{~min}$ (holding stages), followed by 40 cycles at $95^{\circ} \mathrm{C}$ for 1 $\mathrm{s}, 60^{\circ} \mathrm{C}$ for $1 \mathrm{~min}$ (cycling stage), followed by $95^{\circ} \mathrm{C}$ for $15 \mathrm{~s}, 60^{\circ} \mathrm{C}$ for $1 \mathrm{~min}, 95^{\circ} \mathrm{C}$ for $30 \mathrm{~s}$, and $60^{\circ} \mathrm{C}$ for $15 \mathrm{~s}$ (melt curve stage).

\section{RESULTS}

\section{Protocol efficiency, number of meristems and storage conditions}

Total RNA was extracted from a single-active shoot apical meristem. The average concentration of the total RNA extracted with each protocol is shown in Table 2. Protocol 01 was determined to be the most efficient with high concentration and quality of the extracted RNA. 
Table 2. Concentration and absorbance of total RNA samples extracted from a single-active shoot apical meristem of Theobroma cacao.

\begin{tabular}{|l|c|c|c|}
\hline Protocol & Concentration $(\mathrm{ng} / \mu \mathrm{L})$ & Absorbance (260/280) & Absorbance (260/230) \\
\hline 01 (Verica et al., 2004) & 242.1 & 1.9 & 1.8 \\
\hline 02 (Gesteira et al., 2003) & 24.5 & 1.7 & 0.7 \\
\hline ZR Plant RNA mini Prep-Zymo (Zymo Research) & 31.5 & 1.7 & 0.7 \\
\hline RNAqueous (Life Technologies) & 56.6 & 2.0 & 0.7 \\
\hline
\end{tabular}

Subsequent tests indicated that the extraction of total RNA using only one shoot apical meristem was more efficient than using three, five, or ten shoot apical meristems. The protocol 01 was tested using different numbers of apical meristems and concentration of total RNA extracted was $242.1,175.2,150.0$, and $112.8 \mathrm{ng} / \mu \mathrm{L}$ using one, three, five, and ten apical meristems, respectively.

The efficiency of protocol 01 for total RNA extraction from a single-apical meristem subjected to different storage conditions was also assessed. The RNA concentration obtained from the lyophilized, ultra-frozen (at $-80^{\circ} \mathrm{C}$ ), and freshly collected samples was $177.5,242.1$, and $250.2 \mathrm{ng} /$ $\mu \mathrm{L}$, respectively. In addition, the mean concentration of cDNA, reverse transcribed from the RNA extracted from a single-active shoot apical meristem using the protocol 01 , was $1384.5 \mathrm{ng} / \mu \mathrm{L}$.

\section{Statistical differences among protocols}

ANOVA ( $F$ values, 1\% probability) performed on the obtained data revealed statistically significant differences among the different protocols (Table 3). However, no significant differences were observed among the biological replicates used in each protocol.

Table 3. Analysis of variance for the different RNA extraction protocols and for the biological replicates used in each protocol. $(P<0.01)$.

\begin{tabular}{l|c|c|c|c}
\hline Origin of variations & Sum of squares & Average square & F calculated & F critical value \\
\hline Different protocols & $159,777.3$ & $53,259.1$ & $1,460.6$ & 5.292 \\
\hline Biological replicates per protocol & 144.9 & 36.2 & 0.99 & 5.292 \\
\hline
\end{tabular}

In addition, after ANOVA results indicated a significant difference between the extraction protocols, we assessed the magnitude of these differences, using the Tukey test at $5 \%$ probability (Table 4).

Table 4. Tukey test for comparison between average concentrations of RNA extracted using the different protocols.

\begin{tabular}{l|c}
\hline Protocols & Student range (Q) \\
\hline 01 (Verica et al., 2004) and 02 (Gesteira et al., 2003) & 80.6 \\
\hline 01 and ZR Plant RNA mini Prep-Zymo & 68.0 \\
\hline 01 and RNAqueous & 2.6 \\
\hline 02 and ZR Plant RNA mini Prep-Zymo & 11.9 \\
\hline 02 and RNAqueous & 9.3 \\
\hline ZR Plant RNA mini Prep-Zymo and RNAqueous & \\
\hline
\end{tabular}

Tukey $=3.65$ (critical value), $\mathrm{P}<0.05$.

\section{Extracted RNA suitable for reverse amplification}

We showed that the cDNA amplifications with the actin marker by real-time-quantitative polymerase chain reaction (RT-qPCR) were satisfactory (amplification efficiency of $98.387 \%$; Figure 2). The correlation coefficient $\left(R^{2}=0.99\right)$ confirms the efficiency of these amplifications using the samples extracted with the protocol 01. 


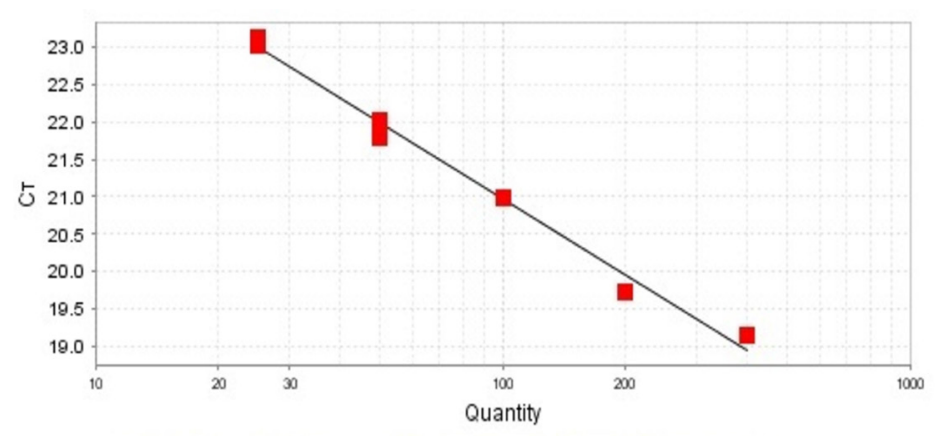

Iarget: act Slope: $-3.361 \underline{\text { Y.Inter: }} 27.69 \underline{\mathrm{R}^{2}}: 0.99 \underline{\underline{\text { Eff }} \%: 98.387}$

Figure 2. Standard curve of the actin marker amplified with CDNA of 'CCN 51' used at five different concentrations (25, $50,100,200$, and $400 \mathrm{ng} / \mu \mathrm{L}) . \mathrm{Ct}=$ cycle threshold; $\mathrm{R}^{2}=$ correlation coefficient; Eff = efficiency.

\section{DISCUSSION}

The extraction of nucleic acids from cacao trees is a laborious process because of the presence of several polyphenolic compounds. The four protocols for RNA extraction evaluated in the present study differed in the reagents used. Protocol 01 used CTAB, phenol, chloroform, lithium chloride, and sodium acetate; it allowed the isolation of total RNA, its dissociation from the proteins and precipitation, and the removal of polysaccharides. Protocol 02 used SDS, boric acid, and tert-butanol; it allowed the denaturation of the proteins, prevented the oxidation of phenolic compounds, and prevented the binding of phenolic compounds to the RNA. The RNAqueous kit had a high concentration of guanidine salts, which enabled cell lysis and inactivation of RNases. The details of the reagents present in the ZR Plant RNA mini Prep-Zymo were not available but the protocol ensured efficient extraction of RNA in $15 \mathrm{~min}$.

We have demonstrated the superiority of the protocol 01 concerning to average concentration and quality of the RNA extracted (Table 2). The ratio of absorbance at 260 and $280 \mathrm{~nm}$ $\left(A_{260 / 280}\right)$ is used to assess the contamination of RNA samples with proteins whereas $A_{260 / 230}$ indicates contamination with polyphenols and polysaccharides (Gasic et al., 2004). The RNA extracted using Protocol 01 showed purity of the samples from polyphenols and polysaccharides while that obtained using all the other protocols was contaminated with these compounds.

The different values of concentrations of total RNA (using one, three, five, or ten shoot apical meristems) were most likely due to the fact that the increased amount of the macerated material in the 2-mL tubes encumbered the extraction process. Also, increasing the amount of material means a greater time required for macerating and greater amount of contaminants and RNAses. This condition favors faster oxidation of macerated material, and degradation of RNA. In addition, although the extraction was effectively achieved from the samples stored under different conditions, the use of fresh samples for RNA extraction could be infeasible for some experiments because nucleic acids degrade very quickly if the samples are not handled or properly stored. The lyophilized samples worked well, but it is advisable to keep the samples in vacuum bags to maintain their integrity for longer period. Finally, storing the samples in an ultra-freezer at $-80^{\circ} \mathrm{C}$ was effective and could be chosen as a fast, safe, and practical option.

ANOVA revealed that the results obtained using the protocol 01 were statistically different from those obtained using all the other protocols. However, the results obtained using the protocol 02 
were not statistically different from those obtained using the ZR Plant RNA Mini Prep-Zymo protocol.

The amplification of the actin gene by RT-qPCR was efficient, which was another indication of the good quality of the samples. In summary, total RNA extracted from a single-shoot apical meristem with the protocol 01 was consistently of satisfactory quality and concentration and yielded good-quality cDNA after reverse transcription. The results indicate that this protocol could be very promising, especially when limited amounts of plant materials are available. This protocol for RNA extraction could, therefore, contribute to the success of molecular studies and the genetic improvement of plants, like the cacao tree, in future.

\section{Conflicts of interest}

The authors declare no conflict of interest.

\section{ACKNOWLEDGMENTS}

Research funded by the Mars Center for Cocoa Science (MCCS) and Conselho Nacional de Desenvolvimento Científico e Tecnológico (CNPq, grants \#307915/2012-3 and \#481074/20139). R.X. Corrêa was the recipient of fellowships from CNPq and D.V. Silva and S.M.J. Branco were recipients of fellowships from Coordenação de Aperfeiçoamento de Pessoal de Nível Superior (CAPES). The authors are grateful to the anonymous reviewer who edited the text for clarity, flow, and better comprehension.

\section{REFERENCES}

Araújo IS, de Souza Filho GA, Pereira MG, Faleiro FG, et al. (2009). Mapping of quantitative trait loci for butter content and hardness in cocoa beans (Theobroma cacao L.). Plant Mol. Biol. Rep. 27: 177-183. http://dx.doi.org/10.1007/s11105$\underline{008-0069-9}$

Ayres M (2011). Bioestat 5.3: aplicações estatísticas nas áreas das ciências biológicas e médicas. 3rd edn. Sonopress, Belém. Available at [www.mamiraua.org.br/pt-br]

Chang S, Puryear J and Cairney J (1993). A simple and efficient method for isolating RNA from pine trees. Plant Mol. Biol. Rep. 11: 113-116. http://dx.doi.org/10.1007/BF02670468

Christou A, Georgiadou EC, Filippou P, Manganaris GA, et al. (2014). Establishment of a rapid, inexpensive protocol for extraction of high quality RNA from small amounts of strawberry plant tissues and other recalcitrant fruit crops. Gene 537: 169-173. http://dx.doi.org/10.1016/j.gene.2013.11.066

Dash PK (2013). High quality RNA isolation from polyphenol-, polysaccharide- and protein-rich tissues of lentil (Lens culinaris). Biotechniques 3: 109-114.

Gasic K, Hernandez A and Korban SS (2004). RNA extraction from different apple tissues rich in polyphenols and polysaccharides for cDNA library construction. Plant Mol. Biol. Rep. 22: 437-438. http://dx.doi.org/10.1007/BF02772687

Gesteira AS, Micheli F, Ferreira CF and Cascardo JC (2003). Isolation and purification of functional total RNA from different organs of cacao tree during its interaction with the pathogen Crinipellis perniciosa. Biotechniques 35: 494-496.

Ghawana S, Paul A, Kumar H, Kumar A et al. (2011). An RNA isolation system for plant tissues rich in secondary metabolites. BMC Res. Notes 4: 85. http://dx.doi.org/10.1186/1756-0500-4-85

Hu CG, Honda C, Kita M, Zhang Z, et al. (2002). A simple protocol for RNA isolation from fruit trees containing high levels of polysaccharides and polyphenol compounds. Plant Mol. Biol. Rep. 20: 69. http://dx.doi.org/10.1007/BF02801935

Mattheus N, Ekramoddoullah AK and Lee SP (2003). Isolation of high quality RNA from white spruce tissue using a three-stage purification method and subsequent cloning of a transcript from the PR-10 gene family. Phytochem. Anal. 14: 209-215. http://dx.doi.org/10.1002/pca.701

Mitra D and Kootstra A (1993). Isolation of RNA from apple skin. Plant Mol. Biol. Rep. 11: 326-332. http://dx.doi.org/10.1007/ BF02905334

Moser C, Gatto P, Moser M, Pindo M, et al. (2004). Isolation of functional RNA from small amounts of different grape and apple tissues. Mol. Biotechnol. 26: 95-100. http://dx.doi.org/10.1385/MB:26:2:95 
Pinheiro TT, Litholdo CG Jr, Sereno ML, Leal Jr GA, et al. (2011). Establishing references for gene expression analyses by RT-qPCR in Theobroma cacao tissues. Genet. Mol. Res. 10: 3291-3305. http://dx.doi.org/10.4238/2011.November.17.4

Portillo M, Fenoll C and Escobar C (2006). Evaluation of different RNA extraction methods for small quantities of plant tissue: Combined effects of reagent type and homogenization procedure on RNA quality-integrity and yield. Physiol. Plant. 128: 1-7. http://dx.doi.org/10.1111/j.1399-3054.2006.00716.x

Rai V, Ghosh JS and Dey N (2010). Isolation of total RNA from hard bamboo tissue rich in polyphenols and polysaccharides for gene expression studies. Electron. J. Biotechnol. 13: 22-23. http://dx.doi.org/10.2225/vol13-issue5-fulltext-17

Rubio-Pina JA and Zapata-Perez O (2011). Isolation of total RNA from tissues rich in polyphenols and polysaccharides of mangrove plants. Electron. J. Biotechnol. 14: 11.

Salzman RA, Fujita T, Zhu-Salzman K, Hasegawa PM, et al. (1999). An improved RNA isolation method for plant tissues containing high levels of phenolic compounds or carbohydrates. Plant Mol. Biol. Rep. 17: 11-17. http://dx.doi. org/10.1023/A:1007520314478

Sharma AD, Gill PK and Singh P (2003). RNA isolation from plant tissues rich in polysaccharides. Anal. Biochem. 314: 319321. http://dx.doi.org/10.1016/S0003-2697(02)00689-9

Silva CR, Albuquerque PS, Ervedosa FR, Mota JW, et al. (2011). Understanding the genetic diversity, spatial genetic structure and mating system at the hierarchical levels of fruits and individuals of a continuous Theobroma cacao population from the Brazilian Amazon. Heredity 106: 973-985. http://dx.doi.org/10.1038/hdy.2010.145

Silva DV, Araújo IS, Branco SMJ, Aguilar-Vildoso Cl et al. (2014). Analysis of resistance to witches' broom disease (Moniliophthora perniciosa) in flower cushions of Theobroma cacao in a segregating population. Plant Pathol. 63: 12641271. http://dx.doi.org/10.1111/ppa.12204

Vasanthaiah HKN, Katam R and Sheikh MB (2008). Efficient protocol for isolation of functional RNA from different grape tissue rich in polyphenols and polysaccharides for gene expression studies. Electron. J. Biotechnol. 11: 42-51. http://dx.doi. org/10.2225/vol11-issue3-fulltext-5

Verica JA, Maximova SN, Strem MD, Carlson JE, et al. (2004). Isolation of ESTs from cacao (Theobroma cacao L.) leaves treated with inducers of the defense response. Plant Cell Rep. 23: 404-413. http://dx.doi.org/10.1007/s00299-004-0852-5

Yu D, Tang H, Zhang Y, Du Z, et al. (2012). Comparison and improvement of different methods of RNA isolation from strawberry (Fragria $x$ ananassa). J. Agric. Sci. 4: 51-56.

Zeng Y and Yang T (2002). RNA isolation from highly viscous samples rich in polyphenols and polysaccharides. Plant Mol. Biol. Rep. 20: 417. http://dx.doi.org/10.1007/BF02772130 